\title{
Patch-Clamp Analysis of Voltage-Activated and Chemically Activated Currents in the Vomeronasal Organ Of Sternotherus Odoratus (Stinkpot/Musk Turtle)
}

D. A. Fadool

M. Wachowiak

J. H. Brann

Follow this and additional works at: https://ecommons.luc.edu/biology_facpubs

Part of the Biology Commons

\section{Recommended Citation}

Fadool, D A, M Wachowiak, and J H Brann. "Patch-Clamp Analysis of Voltage-Activated and Chemically Activated Currents in the Vomeronasal Organ of Sternotherus Odoratus (stinkpot/musk Turtle)." The Journal of Experimental Biology 204, no. Pt 24 (December 2001): 4199-4212.

This Article is brought to you for free and open access by the Faculty Publications and Other Works by Department at Loyola eCommons. It has been accepted for inclusion in Biology: Faculty Publications and Other Works by an authorized administrator of Loyola eCommons. For more information, please contact ecommons@luc.edu. (c) (1) $\Theta \Theta$

This work is licensed under a Creative Commons Attribution-Noncommercial-No Derivative Works 3.0 License. (c) The Company of Biologists Limited 2001 


\title{
Patch-clamp analysis of voltage-activated and chemically activated currents in the vomeronasal organ of Sternotherus odoratus (stinkpot/musk turtle)
}

\author{
D. A. Fadool ${ }^{1,{ }^{*}}$, M. Wachowiak ${ }^{2}$, and J. H. Brann ${ }^{1}$ \\ ${ }^{1}$ The Florida State University, Program in Neuroscience and Molecular Biophysics, Biomedical \\ Research Facility, Tallahassee, FL 32306, USA \\ ${ }^{2}$ Yale University School of Medicine, Department of Physiology, New Haven, CT 06520, USA
}

\section{Summary}

The electrophysiological basis of chemical communication in the specialized olfactory division of the vomeronasal (VN) organ is poorly understood. In total, 198 patch-clamp recordings were made from 42 animals (Sternotherus odoratus, the stinkpot/musk turtle) to study the electrically and chemically activated properties of VN neurons. The introduction of tetramethylrhodamineconjugated dextran into the VN orifice permitted good visualization of the vomeronasal neural epithelium prior to dissociating it into single neurons. Basic electrical properties of the neurons were measured (resting potential, $-54.5 \pm 2.7 \mathrm{mV}, N=11$; input resistance, $6.7 \pm 1.4 \mathrm{G} \Omega, N=25$; capacitance, $4.2 \pm 0.3 \mathrm{pF}, N=22$; means \pm S.E.M.). The voltage-gated $\mathrm{K}^{+}$current inactivation rate was significantly slower in $\mathrm{VN}$ neurons from males than in those from females, and $\mathrm{K}^{+}$currents in males were less sensitive (greater $K_{\mathrm{i}}$ ) to tetraethylammonium. Vomeronasal neurons were held at a holding potential of $-60 \mathrm{mV}$ and tested for their response to five natural chemicals, female urine, male urine, female musk, male musk and catfish extract. Of the $90 \mathrm{VN}$ neurons tested, 33 (34\%) responded to at least one of the five compounds. The peak amplitude of chemically evoked currents ranged from 4 to $180 \mathrm{pA}$, with two-thirds of responses less than $25 \mathrm{pA}$. Urine-evoked currents were of either polarity, whereas musk and catfish extract always elicited only inward currents. Urine applied to neurons harvested from female animals evoked currents that were 2-3 times larger than those elicited from male neurons. Musk-evoked inward currents were three times the magnitude of urine-or catfish-extract-evoked inward currents. The calculated breadth of responsiveness for neurons presented with this array of five chemicals indicated that the mean response spectrum of the VN neurons is narrow ( $H$ metric 0.11 ). This patch-clamp study indicates that $\mathrm{VN}$ neurons exhibit sexual dimorphism in function and specificity in response to complex natural chemicals.

\section{Keywords}

vomeronasal; turtle; pheromone; Sternotherus odoratus; olfaction

\section{Introduction}

Higher vertebrates use chemical communication to distinguish social hierarchy, reproductive status or species (for reviews, see Halpern, 1987; Døving and Trotier, 1998). Specialized chemicals or pheromones are thought to bind to two or three different families of G-protein- 
coupled receptors that transduce this chemical information into an electrical event in the vomeronasal organ, a partition of the olfactory system (for reviews, see Tirindelli et al., 1998; Keverne, 1999; Dulac, 2000) (see also Del Punta et al., 2000; Pantages and Dulac, 2000). The electrical properties of voltage-gated channels in vomeronasal (VN) neurons have been well-studied, but exploration of chemically activated currents has been limited (for a review, see Liman, 1996). Initial studies yielded conflicting data, which may be attributed to the specific animal model or to the limited availability of purified pheromones used for stimulation (Moss et al., 1997, 1998; Trotier et al., 1998). Two recent studies employed the use of $\mathrm{Ca}^{2+}$ imaging and a 64-diode array, respectively, to observe the response profiles of small populations of $\mathrm{VN}$ neurons to single identified pheromones or a natural chemical stimulus (urine) known to elicit endocrine changes or reproductive behavior patterns (Holy et al., 2000; Leinders-Zufall et al., 2000). Because of the small number of cells that responded to these stimuli (approximately 3-5\% of neurons), extensive analysis of the biophysical properties of $\mathrm{VN}$ neurons at the level of the single cell was not possible.

We hypothesized that Sternotherus odoratus, the common musk or 'stinkpot' turtle, would afford an electrophysiological advantage for the study of functional transduction in the vertebrate vomeronasal organ. Turtles are historically well-suited as robust physiological preparations because of their high tolerance of room temperature and oxygen-reduced recording environments compared with mammalian preparations. This particular semiaquatic species has a proportionately larger vomeronasal organ (VNO) compared with the main olfactory epithelium (MOE); the former is separate and easily accessible (Murphy et al., 2001). Sternotherus odoratus also has a well-characterized reproductive physiology and pattern of mating behavior (Carpenter and Ferguson, 1984). The animal secretes a musk produced from specialized glands that it uses in both courtship and predator avoidance (Eisner et al., 1977).

In previous work, we described the developmental and gender-dependent expression of GTP-binding proteins $\left(\mathrm{G}_{\alpha \mathrm{i}}\right.$ and $\left.\mathrm{G}_{\beta}\right)$ and the transient receptor potential channel (trp2) in the musk turtle vomeronasal epithelium (Murphy et al., 2001). The presence of these putative signal-transduction proteins supports their involvement in encoding chemical information, but the functional role of these proteins remains incompletely determined. Ultimately, the initiation and characterization of the electrical event elicited via this transduction cascade shapes the information processed in the VNO. Here, we report a study of the vertebrate VNO in which multiple natural chemicals were presented to single isolated neurons to elicit currents recorded in the whole-cell patch-clamp configuration. Important biophysical properties of these neurons, including a narrow breadth of responsiveness to a chemical and a degree of sexual dimorphism in electrical properties, are described.

\section{Materials and methods}

\section{Solutions and reagents}

$\mathrm{Ca}^{2+}$-free turtle Ringer contained (in mmol ${ }^{-1}$ ): $116 \mathrm{NaCl}, 4 \mathrm{KCl}, 1 \mathrm{MgCl}_{2}, 15$ glucose, 5 sodium pyruvate and 10 Hepes ( $\mathrm{pH}$ 7.4). Turtle Ringer's solution contained (in mmol $\mathrm{l}^{-1}$ ): $116 \mathrm{NaCl}, 4 \mathrm{KCl}, 2 \mathrm{CaCl}_{2}, 1 \mathrm{MgCl}_{2}, 15$ glucose, 5 sodium pyruvate and $10 \mathrm{Hepes}(\mathrm{pH}$ 7.4). The bath solution for recording was Ringer's solution. The intracellular pipette solution contained (in mmol $\mathrm{l}^{-1}$ ): $115 \mathrm{KCl}, 2 \mathrm{MgCl}_{2}, 10$ Hepes, 2.5 ATP and $0.5 \mathrm{GTP}$ (pH 7.4). The nucleotides were prepared daily and added to the pipette solution just prior to recording. Phosphate-buffered saline (PBS) contained (in mmol l-1): $136.9 \mathrm{NaCl}, 2.7 \mathrm{KCl}, 10.1$ $\mathrm{Na}_{2} \mathrm{HPO}_{4}$ and $1.8 \mathrm{KH}_{2} \mathrm{PO}_{4}\left(\mathrm{pH}\right.$ 7.4). Low-Ca ${ }^{2+}$, hyperosmotic dissociation solution (DS) contained (in mmol l-1): $110 \mathrm{NaCl}, 4 \mathrm{NaOH}, 2 \mathrm{KCl}, 1 \mathrm{CaCl}_{2}, 10 \mathrm{Na}_{2} \mathrm{CO}_{3}, 10 \mathrm{NaHCO}_{3}, 10$ sodium citrate and $1 \%$ albumin ( $\mathrm{pH} 10.3$ ). All salts were purchased from either Fisher 
Scientific (Suwanee, GA, USA) or Sigma Chemical Co. (St Louis, MO, USA).

Tetraethylammonium (TEA ${ }^{+}$), DNase I (type II; EC 3.1.21.1) and subtilisin (type XXIV; EC 232-642-4) were purchased from Sigma. Tetrodotoxin (TTX) was purchased from Calbiochem (La Jolla, CA, USA).

\section{Turtle capture and care}

Sternotherus odoratus (stinkpot or common musk turtle) were captured at Auburn University arboretum (Auburn, AL, USA), Lake Jackson (Tallahassee, FL, USA) or Indian Pines (Opelika, AL, USA) [mean male plastron length was $56.5 \pm 1.9 \mathrm{~mm}(N=10)$ while that of the female was $60.4 \pm 0.8 \mathrm{~mm}(N=22)$; mean male mass was $88.6 \pm 7.6 \mathrm{~g}(N=10)$ compared with $98.0 \pm 3.9 \mathrm{~g}(N=22)$ for females; means \pm S.E.M.] from April to September, the approximate peak reproductive season for this species (Carpenter and Ferguson, 1984). Turtles were captured either by hand or using raw chicken-baited hoop nets $0.3-1 \mathrm{~m}$ in diameter. Turtles were housed for periods of 1-2 months in 381 aquaria, maintained on a 15 h:9 h light:dark cycle and fed a standard diet of chicken, beef or catfish pellets. Southern populations of $S$. odoratus reach reproductive maturity at 4 years of age (Tinkle, 1961). Dr Mary Mendonça, a reproductive herpetologist at Auburn University, assessed that all the animals in this study were adults by noting secondary sexual and other developmental characteristics such as an enlarged tail base, scale patches on the hind legs, unmarked patterning of the carapace, the absence of a vertebral keel and a carapace length greater than $60 \mathrm{~mm}$ (Ernst et al., 1994). In addition, the majority of females at this age had developing eggs in the oviduct.

\section{Collection of natural body fluids}

Musk was harvested from the turtles by milking the posterior, reproductive musk glands. Approximately 1-2 $\mu 1$ of musk could be obtained from one animal. Urine was collected through a 27 gauge needle inserted directly into the bladder. The collected fluids were immediately placed on ice and then stored at $-80{ }^{\circ} \mathrm{C}$ until diluted in turtle Ringer for experimentation. Urine and musk samples used in this study were collected over the 19982000 summer reproductive months (April-September).

\section{Vital dye labeling and cryosectioning}

Turtles were immobilized and anesthetized using ice hypothermia for $30 \mathrm{~min}$. Tetramethylrhodamine-conjugated dextran $\left(M_{\mathrm{r}} 10000\right.$, neutral; Molecular Probes, Eugene, OR, USA) was introduced into the VNO orifice using a handmade syringe pump that delivered $7 \mu 1$ to the cavity (Friedrich and Korsching, 1997; Wachowiak and Cohen, 1999). The dextran dye was diluted in PBS plus $0.5 \%$ Triton-X 100 to a final concentration ranging between 2 and $4 \%$ and applied for $20 \mathrm{~min}$. The animal then recovered at room temperature $\left(23{ }^{\circ} \mathrm{C}\right)$ for $30 \mathrm{~min}$ prior to reintroduction into the aquarium. After migration of the dye over a 2-week period, turtles were reanesthetized on ice and were given a lethal injection of sodium pentabarbitol (Butler Company, Columbus, OH, USA) before decapitation. The VNO and combined olfactory bulb (OB) and accessory olfactory bulb (AOB) were quickly dissected from the turtles using methods approved by the American Veterinary Association and NIH, as reviewed by the Animal Care and Use Committees of Florida State University and the Marine Biological Laboratories.

For cryosections, whole VNOs and combined OB/AOBs were fixed in $4 \%$ paraformaldehyde in PBS for $3 \mathrm{~h}$ followed by overnight infiltration with $10 \%$ sucrose in PBS and then $4 \mathrm{~h}$ with $30 \%$ sucrose in PBS. Tissues were cut to a thickness of $9-12 \mu \mathrm{m}$ on an Ames Microtome-Cryostat (model 4550; Tarrytown, NY, USA). Sections were transferred to $1 \%$ gelatin-coated glass slides (Sigma) and stored at $-20{ }^{\circ} \mathrm{C}$ until use. 


\section{Histochemistry and photomicroscopy}

Rhodamine-conjugated dextran-labeled cryosections were viewed at 10x and 40x magnification without any further treatment using a Nikon Microphot-FX (Melville, NY, USA) microscope equipped with epifluorescence and a Nikon FX35WA automatic photomicrographic system using Kodak Elite II 400 ASA film. Other cryosections were histochemically stained using standard protocols for Masson's Trichrome staining as cited by Humason (1972). In both instances, $35 \mathrm{~mm}$ films were scanned with a Hewlett-Packard Photosmart Scanner (model 106-816) or a Nikon LS2000. Digital files were imported into Photoshop (Adobe 5.5) to facilitate multiple panel/figure output on a Fuji Pictographic 3000 printer.

\section{Electrophysiology}

Turtles were anesthetized on ice and then killed by administering a lethal injection of sodium pentabarbitol (Butler Company) followed by decapitation. Neurons from the VNO were isolated either by incubation in a low- $\mathrm{Ca}^{2+}$, hyperosmotic dissociation saline (DS) followed by a brief incubation in $0.50 \mu \mathrm{gml}^{-1}$ DNase I solution or by incubation in $\mathrm{Ca}^{2+}$ free, cysteine-activated papain (50 units; Worthington Biochemicals, Lakewood, NJ, USA) in turtle Ringer. For either dissociation protocol, the VNO was cut into quarters and incubated in appropriate dissociation saline for $15-18 \mathrm{~min}$ with gentle rotation at 30 revs $\mathrm{min}^{-1}$ on an orbital shaker at room temperature. Tissue quarters were then removed from the incubation saline and placed into cold turtle Ringer. Tissue quarters could be held at $4{ }^{\circ} \mathrm{C}$ for up to $8 \mathrm{~h}$ prior to physical dissociation. A VNO quarter was dissociated by trituration using a size-graded series of fire-polished siliconized Pasteur pipettes. The resulting single vomeronasal cells were plated onto $0.01 \%$ poly-D-lysine-hydrobromide-coated $\left(M_{\mathrm{r}} 49000\right.$ 53 000; Sigma) and $0.1 \%$ laminin-coated (laminin-like engineered protein polymer, Sigma) Corning dishes (Fisher no. 25000) (Leinders-Zufall et al., 1997).

Isolated vomeronasal neurons were viewed at 40× magnification (Axiovert 135, Carl Zeiss, Thornwood, NY, USA) with Hoffman modulation contrast optics for patchclamp recording (Hamill et al., 1981). Patch pipettes were fabricated from Jencons borosilicate glass (catalog number M15/10; Jencons Limited, Bedfordshire, UK), fire-polished to approximately $1 \mu \mathrm{m}$ (bubble number 5.0) (Mittman et al., 1987) and coated near the tip with beeswax to reduce the pipette capacitance. Pipette resistances were between 7 and $10 \mathrm{M} \Omega$, which produced high-resistance seals (between 8 and $14 \mathrm{G} \Omega$ ) by applying gentle suction to the lumen of the pipette upon contact with the cell. In all experiments, cells were voltage-clamped at a holding potential $\left(V_{\mathrm{h}}\right)$ of $-60 \mathrm{mV}$ unless specified otherwise. Each cell was photographed (Minolta X-700, Ramsey, NJ, USA) to allow for correlation of soma size, length of process and cell morphology with physiological properties.

Voltage- and chemically activated currents were recorded in the whole-cell configuration using an integrating patch-clamp amplifier (Axopatch 200B, Axon Instruments, Foster City, CA, USA). The analog output was filtered at $5 \mathrm{kHz}$ and digitally sampled every $0.5-4 \mathrm{~ms}$. Data acquisition and subsequent storage and analysis of the digitized recordings were carried out using pClamp8.0 software (Axon Instruments) in combination with the analysis packages Origin (MicroCal Software, Northampton, MA, USA) and Quattro Pro (Borland International, Jericho, NJ, USA). Data traces were subtracted linearly for leakage conductance. The inactivation of the outward macroscopic current was fitted to a singleexponential function by minimizing the sums of squares. Differences between sexes in a particular biophysical property were analyzed by $F_{\max }$-test and then by Student's $t$-test. No tests with unequal sample sizes violated homogeneity of variance (i.e. none failed the $F_{\max ^{-}}$ test), and statistical significance in all tests was defined at the 95\% confidence interval (Steel and Torrie, 1980). 


\section{Chemical stimulation}

Chemicals were puffer-applied to the vomeronasal neurons for $700 \mathrm{~ms}$ from a sevenbarrelled glass micropipette (1.2 mm outer diameter, catalog no. 17-12-M; Frederick Haer, Bowdoinham, ME, USA) coupled to a pressurized valve system (Picospritzer, General Valve, Fairfield, NJ, USA) (Fadool et al., 1991). In most trials, fluorescein, the position of which was varied from one experiment to another, was used as an indicator in one barrel of the pipette to position the tip of the pipette relative to the cell and to ensure that the delivered compound completely surrounded the cell and its associated processes. The magnitude of the response to $0.5 \mathrm{~mol}^{-1} \mathrm{KCl}$ was found to be independent of which of the six barrels contained the depolarizing solution. Dilution of the chemical between the pipette and the cell surface, an average distance of two cell diameters, was estimated to be approximately $9 \%$ on the basis of the calculated $\mathrm{K}^{+}$permeability method of Firestein and Werblin (1989).

Chemical concentrations are reported as the pipette concentration and are not corrected for this dilution. The pipette concentration of urine varied between 1:5 and 1:20 dilution from full strength and that for musk varied between 1:100 and 1:300. Catfish extract was prepared from a commercially available pellet (Florida Farm and Feed, Tallahassee, FL, USA). Pellets $(2 \mathrm{~g})$ were hydrated in $20 \mathrm{ml}$ of high-quality water, ground by mortar and pestle, and then clarified by low-speed centrifugation for $5 \mathrm{~min}$ at room temperature. The extract was stored at $-80^{\circ} \mathrm{C}$ and diluted 100 -to 1000 -fold for use. All dilutions were prepared daily in turtle Ringer, which served as the control vehicle in all conditions.

If a neuron responded to the control, it was assumed to be a mechanical stretch-activated response, and no further use was made of the cell. The peak magnitude of a response was measured as the difference in current from the baseline prior to presentation of the chemical to the peak outward- or inward-evoked current within $500 \mathrm{~ms}$ of valve activation of the picospritzer. Zero current (no response) was defined as no observable deflection or a deflection that was less than four times the total noise level (membrane plus equipment) under control baseline conditions.

The number of different compounds that stimulated a given cell (the response spectrum) was quantified using the breadth of responsiveness metric of Smith and Travers (1979). Here, the breadth of responsiveness $(H)$ is defined as:

$$
H=-K \sum_{i=1}^{n} p_{i} \log p_{i}
$$

where $K$ is a proportionality constant, $n$ is the number of chemicals tested, $p_{\mathrm{i}}=|\mathrm{pA}|$ is the absolute current (pA) elicited by the $n$th chemical and expressed as a proportion of the total current elicited by all chemicals. This equation is an application of the entropy equation as a measure of diversity in neural responsiveness. The $p_{\mathrm{i}}$ values for each neuron are derived by converting the neural response profile for that neuron into a proportional profile in which the response to each chemical is expressed as a proportion of the total response to all five chemicals (Smith and Travers, 1979). The value of $K=1.4306$ was calculated so that $H=1.0$ when $p_{\mathrm{i}}=1 / n$. Therefore, when there is a response to only one of the five chemicals, the breadth of responsiveness is minimal $(H=0)$, and it is maximal $(H=1.0)$ when there is an equal response to each of the five chemicals (no selectivity or diversity in response) (Smith and Travers, 1979). 


\section{Results}

\section{Vomeronasal epithelium and neuronal morphology}

The introduction of tetramethylrhodamine dextran with Triton-X 100 into the vomeronasal orifice permitted good visualization of the organization of $\mathrm{VN}$ neurons in the vomeronasal epithelium (VNE) prior to dissociation to single cells (Fig. 1). Presumably, the membraneimpermeant dextran dye, when combined with the detergent Triton-X 100, gains access to the neuronal population of cells in the VNO when the detergent disrupts or shears the microvilli of the sensory neurons. The dye was introduced into the left VNO orifice, and the labeling demonstrated in Fig. 1A suggested that access was restricted to that side of the organ, given the absence of labeling on the right side of this bilaterally symmetrical organ.

Once a male Sternotherus odoratus is within visual proximity of a female, the male can enter the tactile phase of courtship by sampling the secretion of the posterior musk gland with his nasal passages through physical contact between the nose and the gland (Mahmoud, 1967). It is not known whether the secretion is detected in the MOE or the VNO or in both partitions of the olfactory passages. The dye-labeling experiments shown in Fig. 1 do, however, demonstrate that molecules delivered into the VNO can be restricted to that portion of the epithelium and do not traverse to the contralateral side of the organ. Fig. 1B is a higher magnification of the labeled VNE demonstrating the basal position of the neuronal somata and the apical extension of dendrites into the microvillar layer, the presumed site of chemosensory transduction. After 2 weeks, labeled dextran could be detected in the glomeruli of the accessory olfactory bulb (AOB), where it appeared to fill the presynaptic VN nerve endings (Fig. 1C). Fig. 1D is a brightfield micrograph of a dextran-labeled cryosection counterstained with Masson's Trichrome to highlight the neural epithelium and underlying connective tissue. Three adult animals (two female, one male) were labeled with rhodamine-conjugated dextran and several standard histological stains (data not shown); all had staining similar to that shown in Fig. 1. Although Triton-X 100 treatment did not appear to alter the biophysical properties of cells harvested from these dextran-stained animals, only unlabeled animals were used in subsequent electrophysiological experiments described below.

Several protocols for dissociation of neurons were explored to achieve acute isolation of single vomeronasal neurons and, ultimately, to preserve the proteins of the chemosensory receptors and related signal cascade. The least mechanical damage and tightest seals were achieved with a low-Ca ${ }^{2+}$, hyperosmotic dissociation saline (Dionne, 1992) or a weak and brief incubation in cysteine-activated papain (see Materials and methods). Both these methods yielded viable neurons with identical electrophysiological properties. Since the latter method was less time-consuming and more reliable, all neurons used to generate results for this report were subjected to this brief papain treatment for dissociation. Doubling the papain concentration, long orbital rotations, isolation with DNase I only, mechanical trituration without the use of a siliconized pipette surface or incubation with the bacterial enzyme subtilisin resulted in the loss of either voltage-activated $\mathrm{Na}^{+}$currents or chemically activated currents or resulted in an inability to patch the VN membrane, even though each of these protocols has been used to isolate neurons in other sensory organs (Fadool et al., 1993; Lumpkin and Hudspeth, 1995; Trotier et al., 1998).

Isolated $\mathrm{VN}$ neurons were viable for up to $8 \mathrm{~h}$ following initial dissection of the organ. The neurons had a morphology similar to that observed in other vertebrate species (Taniguchi et al., 1995; Trotier et al., 1998), namely a distinct lengthy dendrite terminating in a tuft of microvilli (Fig. 1E,F). In preparations that were first dextran-labeled and then dissociated, the morphological cell type shown in Fig. 1E,F was consistently labeled. Cells of fusiform or spherical soma morphology, both of which lacked processes, were not studied. Cells of 
varying dendritic process length and soma diameter were deliberately sampled to ascertain whether a particular neuronal morphology was correlated to a higher degree of either voltage- or chemically activated sensitivity. The mean soma diameter of VN neurons harvested from female animals was significantly greater than that calculated for male animals $(8.5 \pm 1.6 \mu \mathrm{m}, N=68$ for females; $7.4 \pm 1.5 \mu \mathrm{m}, N=32$ for males; Student's $t$-test, $\alpha=0.05$, means \pm S.E.M.) (Fig. 2A,B). The mean process length for neurons from male animals was $45.9 \pm 32.7 \mu \mathrm{m}(N=27)$ and that from female animals was $35.6 \pm 20.0 \mu \mathrm{m}(N=60)$ (Fig. 2C,D), and these values were not significantly different (Student's $t$-test, $\alpha=0.05$ ). We could not determine whether the high variability in process length was real or was attributable to the dissociation process. The following measurements were made in both sexes and found to be gender-independent, with correlations coefficients ranging from $r=$ -0.27 to +0.26 : dendritic length or soma diameter versus chemically activated current magnitude; dendritic length or soma diameter versus voltage-activated $\mathrm{Na}^{+}$current magnitude; and dendritic length or soma diameter versus inactivation kinetics of $\mathrm{K}^{+}$ currents. Because no strong correlation $(r>0.90)$ existed between cell shape and evokedcurrent properties, subsequent data were not grouped by morphology (i.e. dendritic process length or soma diameter) but were treated as a whole.

\section{Membrane and voltage-activated properties}

In total, 198 recordings were made from 24 animals to study the electrical properties of VN neurons by patch-clamping in the whole-cell configuration. The resting potential $\left(V_{\mathrm{m}}\right)$ of a sample population of these neurons was $-54.5 \pm 2.7 \mathrm{mV}$ (means \pm S.E.M., $N=11$; range -38 to $-64 \mathrm{mV})$. The input resistance was $6.7 \pm 1.4 \mathrm{G} \Omega(N=25)$ with a mean capacitance of $4.2 \pm 0.3 \mathrm{pF}(N=22)$. These $\mathrm{VN}$ neuron membrane and voltage-activated properties measured in Sternotherus odoratus were comparable with those reported in other vertebrate models. Vomeronasal neurons from mammals, reptiles and amphibians therefore possess a full array of voltage-activated channels necessary to produce action potentials (Trotier et al., 1993; Taniguchi et al., 1995; Liman and Corey, 1996; Inamura et al., 1997a; Moss et al., 1997, 1998; Døving and Trotier, 1998; Trotier et al., 1998). Across phyla, and inclusive of data from the present study, the resting membrane potential of $\mathrm{VN}$ neurons is on average $30 \mathrm{mV}$ more depolarized than that reported for olfactory sensory neurons. In $S$. odoratus, voltageactivated currents were elicited by clamping neurons at a holding potential of $-70 \mathrm{mV}\left(V_{\mathrm{h}}\right)$ and stepping in $10 \mathrm{mV}$ depolarizing increments for $400 \mathrm{~ms}$ (Fig. 3). The total membrane current evoked in a typical cell consisted of a rapid inward current $(\leq 10 \mathrm{~ms}$ duration) that activated around $-40 \mathrm{mV}$, followed by an outward current that contained both a transient and a sustained component, which activated between potentials of -40 and $-30 \mathrm{mV}$. This pattern of activation can be seen in the current/voltage (I/V) relationships (Fig. 3B,D) for the family of traces presented in Fig. 3A,C. Although the peak sustained and transient outward currents at $+40 \mathrm{mV}$ depolarization are not significantly different in neurons from male and female animals (Table 1), the inactivation rate constant was markedly slower in males (448 ms, $N=25$ ) than in females ( $303 \mathrm{~ms}, N=83$ ) (Student's $t$-test, $\alpha=0.05$ ) (Table 1 ). The time to half-activation of the outward current, as measured at $+40 \mathrm{mV}$, was $2.1 \pm 0.4 \mathrm{~ms}(N=83)$ in females and slightly slower in males $(3.4 \pm 0.6 \mathrm{~ms}, N=25)$ (not significantly different, Student's $t$-test, $\alpha=0.05$ ) (Fig. 3E). In addition, the peak inward current, as measured at the $-20 \mathrm{mV}$ step, was significantly greater in neurons from male animals than in those from females (Table 1) (Student's $t$-test, $\alpha=0.05$ ). Although the underlying mechanism for sexually dimorphic voltage-gated properties in these neurons is not known, it is clear that different ion channel properties expressed in neurons from the two sexes could contribute to the ultimate shape and duration of the action potential.

If a difference in $\mathrm{Na}^{+}$or $\mathrm{K}^{+}$channel composition existed between males and females, we reasoned that this might be detected through distinct pharmacological probes directed at the 
conserved binding domains of these voltage-gated channels. The inward voltage-gated currents of both sexes were equally sensitive to tetrodotoxin (TTX) with a half-maximal inhibition concentration $\left(K_{\mathrm{i}}\right)$ of $2.5 \mathrm{nmol}^{-1}$ for females and $2.6 \mathrm{nmol}^{-1}$ for males (data not shown). These very similar $K_{\mathrm{i}}$ values suggest that a similar voltage-gated $\mathrm{Na}^{+}$channel species is expressed in both sexes. The outward voltage-activated currents in neurons of both sexes were sensitive to tetraethylammonium $\left(\mathrm{TEA}^{+}\right)$. Dose/response data for these two groups of neurons are shown in Fig. 4 and indicated a greater $K_{\mathrm{i}}$ in males than in females (transient component $K_{\mathrm{i}}=2.4 \mathrm{nmol} \mathrm{l}^{-1}$ versus $2.0 \mathrm{nmol} \mathrm{l}^{-1}$; sustained component $K_{\mathrm{i}}=4.8$ nmol $1^{-1}$ versus $1.7 \mathrm{nmol}^{-1}$ ). These data are consistent with the expression of $\mathrm{K}^{+}$channels with different $\mathrm{TEA}^{+}$binding affinity between the genders.

\section{Chemically activated properties}

Ninety neurons from a total of 18 animals were tested for their ability to generate a current in response to stimulation with up to five different natural chemicals. For all trials, neurons were clamped at a membrane potential of $-60 \mathrm{mV}$, a potential at which there was no voltage-gated channel activity (Fig. 3). Current responses typically rose to a maximum over several hundred milliseconds and subsequently declined to rest over a period of 3-4 s (Fig. $5 \mathrm{~A}, \mathrm{~B})$. Although the properties of adaptation were not formally tested, current responses to applied chemicals were repeatable in a neuron for periods as long as $50 \mathrm{~min}$ or the duration of the patch-seal integrity. Typically, a current response to a chemical applied five times during a 50 min recording period yielded responses that varied by $2-5 \%$. The chemicals that were tested elicited a current response in 33 of the 90 cells tested (34\%). Of the 33 responsive cells, 14 cells $(42 \%)$ responded to only one of the five chemicals presented in the array. The other responsive cells ( 19 cells, $58 \%$ ) responded to two or more chemicals (Fig. 5C). The number of cells responding is plotted against the peak current magnitude in Fig. $6 \mathrm{~A}$ to best visualize the distribution of response magnitudes in these neurons.

Chemically activated currents could be of either polarity, depending upon the cell and the chemical tested. The majority of the responses elicited were inward currents, as shown in Fig. 6B. Female urine and male urine evoked both outward and inward currents, whereas female musk, male musk and catfish extract evoked only inward currents. The stimulus most frequently eliciting a current response was female urine. The stimulatory effectiveness of the natural compounds (listed in order of probability of evoking a response) was female urine $>$ male urine $>$ male musk $>$ female musk $>$ catfish extract (Fig. 6B). Vertebrate urine is known to contain elevated levels of salts, particularly $\mathrm{K}^{+}$salts (Vander, 1995), that could artificially drive depolarization in the VN neurons. Even though dilution of urine samples (1:10-1:20) presumably alleviated this potential artifact, high $\mathrm{K}^{+}$levels would have produced uniform depolarization in all cells, unlike the diversity of response profiles observed in our experiments. In addition, boiled urine (to denature protein, but retain salt) $(N=31)$ failed to elicit responses in the $\mathrm{VN}$ neurons, whereas dialyzed urine (elimination of salt) $(N=26)$ elicited the same response frequency as control urine samples.

The peak amplitude of currents of both polarities evoked from the five natural stimuli ranged from -92 to $180 \mathrm{pA}$ (Fig. 6A), demonstrating a degree of variability. The mean magnitude of the inward current $(-13.2 \pm 3 \mathrm{pA}$, mean \pm S.E.M., $N=48)$ was significantly less than that of the outward current $(36.5 \pm 18 \mathrm{pA}$, mean \pm S.E.M., $N=9)$ irrespective of the type of chemical stimulus ( $N=57$ responses to chemicals, recorded from 33 neurons; $t^{\prime}$-statistic, $\alpha=0.05$ ). In selecting a mate, Sternotherus odoratus has the capacity to orient towards the opposite sex by using water-borne chemical cues up to a $1.6 \mathrm{~km}$ radius from the site of release (Carpenter and Ferguson, 1984). Urine could act as this chemical cue, and the pheromone constituents in mammalian urine are thought to be plural, with the ability to alter inter-male aggression and endocrine behavior patterns (Chateau et al., 1976; Johns et al., 
1978; Menzies et al., 1992). Our electrophysiological data indicate that both male and female urine are detected by VN neurons harvested from musk turtles of both sexes.

Female urine and male urine applied to neurons harvested from female animals evoked inward currents that were approximately 2-3 times larger than those elicited by the same compounds presented to neurons harvested from male animals. It is not clear whether large urine-evoked currents in females are important for the coding of this signal, but it is noteworthy that $90 \%$ of the outward currents were elicited by urine and detected by female $\mathrm{VN}$ neurons. The peak inward current elicited by female urine or male urine in female VN neurons was, however, significantly smaller than that evoked by female musk or male musk (Table 2). Musk-evoked inward currents were three times the mean magnitude of urineevoked or catfish-extract-evoked inward currents (Fig. 5) (Table 2). Neurons harvested from female animals exhibited musk-activated inward currents, while those harvested from male animals failed to respond to musk, whether it was female or male musk (Table 2).

In an additional, separate experiment, 36 cells that responded to at least one of the five natural chemicals were analyzed to determine their response spectra or diversity of neural response (Fig. 7). The cells varied in the number of chemicals to which they responded and in the magnitude and the polarity of the response to a given stimulus (Fig. 7A). The frequency of the breadth of responsiveness $(H)$ for this sample population is plotted in Fig. 7B $(H=0.11)$. This mean $H$ metric is consistent with the majority of $\mathrm{VN}$ neurons being most selective to a single chemical, since the relative magnitudes of the responses enter into the calculation for entropy.

\section{Discussion}

Many secretions or excretions used for communication among vertebrates consist of mixtures of a large number of compounds (Johnston, 1998). The importance of odor mixture interactions compared with single compounds has been studied electrophysiologically in the main olfactory system (Livermore et al., 1997). Thus, for a sensory organ that mediates social recognition, gender recognition and reproductive readiness (Halpern, 1987), it was important to test biologically significant chemicals or natural secretions at the level of the single VN neuron to understand the electrical events during transmission of chemical information in the VNO. Most cells are chemically irritable (Lerner et al., 1990), but our data indicate that $\mathrm{VN}$ neurons are selectively excitable to several natural compounds. The VN neurons tested for chemically evoked currents did not all respond identically to the same compound, as is classically observed in neurons responding to other chemicals, such as neurotransmitters or neuromodulators. The diversity of response profiles (Fig. 7) strongly indicates that the responses were truly chemosensory in nature. Moreover, the VN neurons exhibited a degree of selectivity (mean $H$ metric value 0.11 ) to a natural chemical when presented with an array of five different compounds. This index is sensitive to subtle distinctions among neuron response profiles and demonstrates a distinct breadth of responsiveness for each $\mathrm{VN}$ neuron. The calculated breadth of responsiveness supports selectivity, which is an important characteristic of chemoreception. The $H$ metric can be compared with that of olfactory neurons $(H=0.2-0.35)$ and of gustatory neurons $(H=0.546)$, which show a slightly greater mean breadth (Smith and Travers, 1979; Derby et al., 1984; Fadool et al., 1993).

Sternotherus odoratus initiates courtship by tactile contact between the nose of the male and the posterior musk gland and cloacal region of the female. If the male finds the female suitable for mating, through chemical cues in the musk or urine, he will bite her head and climb to position her under his plastron (ventral shell surface) for mating (Ernst et al., 1994). Although it is not clear whether these sampled odors are processed through the VNO or the 
MOE, our data demonstrate that both male and female musk evoke inward currents in neurons of the vomeronasal organ. The magnitude of musk-evoked inward currents is 3-5 times that evoked by urine, implying that this compound could provide a different chemical or reproductive cue encoded by strength of response. Unlike urine, musk elicits only inward current, not currents of either polarity. Interestingly, and uncommon in olfactory sensory neurons, the chemosensitivity of the VN neurons is also gender-dependent. The peak magnitude of urine-evoked currents from female $\mathrm{VN}$ neurons is three times that elicited in male VN neurons.

Most unexpected, and incongruent with the reproductive behavior of this species, is the fact that male VN neurons failed to respond to female or male musk. It is possible that the component(s) in the musk to be detected by the male VN neuron is not completely soluble in the manner in which we are applying the stimuli to the neuron. It is also conceivable that the component(s) in the musk is quite labile and that the more sensitive female VN neurons have the ability to retain electrical responses to this component(s) whereas male VN neurons do not. It cannot be ruled out that the failure of these male neurons to detect female or male musk was a result of the small number of male animals that we were able trap. Further electrophysiological studies are needed to increase the number of male VN neurons sampled. The present study was undertaken utilizing $S$. odoratus trapped during the peak breeding season only, and it will be interesting to test the chemosensitivity of non-breeding animals captured during the winter months and of animals captured prior to reproductive maturity (as juveniles). We have previously demonstrated that juvenile $S$. odoratus express a distinct G-protein that appears to be redistributed to the microvillar layer following maturation to adult animals (Murphy et al., 2001). It would be interesting to determine whether the components of the electrical transduction event, as assessed biophysically, were also expressed differently in juveniles.

The majority of chemically activated responses were inward currents of moderate amplitude (less than $25 \mathrm{pA}$ ), but a small proportion of the responses were outward currents (Fig. 6). It is noteworthy that no single responsive $\mathrm{VN}$ neuron was observed to produce chemosignal responses of both polarities, but our data cannot rule out this possibility. The data are not inconsistent with having two signal-transduction cascades operational in this population of VN neurons, each mediating either an inward or an outward current. This suggests that there could be two different functional neuronal types in the vomeronasal organ, each containing different signaling cascades, rather than a single neuron containing dual transduction cascades. Further experimentation will be required to clarify this.

Pharmacological and kinetic data suggest that the balance of the contribution of voltageactivated channels in VN neurons may be slightly different across species. In mammalian and amphibian VN neurons, there is a TTX-sensitive and a TTX-insensitive $\mathrm{Na}^{+}$current (Trotier et al., 1993; Liman and Corey, 1996; Inamura et al., 1997a), whereas in S. odoratus the $\mathrm{Na}^{+}$current is completely blocked by TTX and its magnitude is much smaller. In the frog VNO, the outward $\mathrm{K}^{+}$current was only slightly deactivated after $250 \mathrm{~ms}$ (Trotier et al., 1993). In the turtle (present report) (Taniguchi et al., 1996) and in mammals (Liman and Corey, 1996; Inamura et al., 1997b), there are two kinetic components of $\mathrm{K}^{+}$current inactivation, which is consistent either with two channel species or a single channel type with multiple kinetic rates of inactivation. Also similar in these two models is the relatively slow rate of activation of the $\mathrm{K}^{+}$current; in the mouse, the time to half-activation is of the order of $10 \mathrm{~ms}$ and in the turtle it is $2-4 \mathrm{~ms}$ (depending upon sex), whereas mammalian olfactory sensory neurons are rapidly activated with a half-activation time of $1.3 \mathrm{~ms}$ (Liman and Corey, 1996). 
Earlier electrophysiological studies did not correlate voltage-activated properties with the sex of the animal, so it is not clear whether the dimorphic biophysical properties observed in the musk turtle reflect general principles of vertebrate $\mathrm{VN}$ neurons or are restricted to this species, which is clearly dimorphic in body size (Ernst et al., 1994). It is curious that, in the musk turtle, the transient component of the outward current makes a longer contribution to the $\mathrm{K}^{+}$current in neurons from males than from females. The differential inactivation kinetics of the outward current would be consistent with the presence of two different channel species in the two sexes. Because only a fraction of the $\mathrm{K}^{+}$current would be activated during the 1-3 ms required for an action potential to rise from 0 to $+40 \mathrm{mV}$ in the VNO (Liman and Corey, 1996), male VN neurons would have the capacity to carry a larger fraction of the current during this period, which is critical for achieving threshold and interspike frequency. The additional difference in inward current between sexes would be consistent with a greater current density of $\mathrm{Na}^{+}$channels in male compared with female neurons, with a concomitant enhanced electrical excitability of the male VN neuron.

Recent electrophysiological studies suggest that there may be differences in the properties of chemically activated currents of VN neurons amongst species (Inamura et al., 1999; Inamura and Kashiwayanagi, 2000; Taniguchi et al., 2000). Very different when comparing the chemically activated current in turtle neurons with that in rat and snake neurons are the polarity, the magnitude and the rate of activation and recovery of the response. The response polarity for turtle VN neurons to urine could be both inward or outward, whereas only inward currents have been reported in rat (Inamura and Kashiwayanagi, 2000). The mean response magnitude for inward currents in the turtle was approximately one-third to half the magnitude of those reported for rat. By comparison, the mean value for snake chemically activated currents was 25 times larger (791 pA) than for either rat or turtle (Taniguchi et al., 2000). The most striking difference in the three species is the kinetics of the response. Turtle VN neurons respond to a $700 \mathrm{~ms}$ chemical stimulation within several hundred milliseconds, and the response decays to baseline levels over 3-4 s (Fig. 5). In rat and snake, a 15-20 s stimulation is required for full development of the response. The response then decays to baseline levels over 30-240 s. In spite of differences in the chemical delivery systems and recording configurations in these studies, the response profiles and underlying activation mechanisms must have inherent differences. Both turtle and snake appear to use the VNO to detect compounds derived from prey items (catfish extract in the case of turtles and earthworm secretion in the case of snakes) (Luo et al., 1994; Taniguchi et al., 2000). These data suggest the possibility that, in some species, the VNO may subserve a function for prey identification and not function solely for reproductive and social chemical communication.

Several informative electrophysiological studies have been conducted in the turtle and, although none has explored chemically activated currents using whole-cell patch-clamp recording, they contribute to our knowledge of the biophysics of these neurons. It is important to note that the relative size and function of the two olfactory divisions [main olfactory epithelium (MOE) versus vomeronasal organ (VNO)] have been shown to be extremely habitat-dependent in turtles. Caution must be taken in interpreting the function or biophysical properties of these neurons without regard to species. The earliest electrophysiological studies on the VNO relied on extracellular recordings and were modeled on a terrestrial species, Terrapene carolina. In this species, it was found that general odorants caused an increase in action potential firing in both the VNO and MOE, but that several single compounds could be detected at concentrations two orders of magnitude lower by the MOE compared with the VNO (Graziadei and Tucker, 1970).

Most recent electrophysiological studies in turtle VNO were modeled on a semi-aquatic species, Geoclemys reevesii, and demonstrated that patch electrode dialysis of either cyclic AMP or inositol 1,4,5-trisphosphate $\left(\operatorname{InsP}_{3}\right.$ ) evoked inward currents in these $\mathrm{VN}$ neurons 
(Taniguchi et al., 1995, 1996). In G. reevesii, no chemical has been identified that activates either the cyclic AMP or the InsP $\mathrm{P}_{3}$ cascade, so the biological roles of these secondmessenger-gated ion channels have not been determined. Given the localization of $\mathrm{G}_{\mathrm{i} \alpha}$ and $\mathrm{G}_{\beta}$ G-proteins to the microvillar layer in S. odoratus (Murphy et al., 2001), either or both of these messengers could mediate chemically activated currents in the musk turtle. A role for $\mathrm{Ins}_{3}$ signaling pathways in musk turtles is suggested by the presence of transient receptor potential channel expression (Murphy et al., 2001) and type III $\mathrm{InsP}_{3}$ receptor expression (Fadool et al., 2001) in western blot analyses of purified VNO membranes. We do not know how or whether these proteins are gated by natural chemicals, but our preliminary findings indicate that the type $\mathrm{III} \mathrm{InsP}_{3}$ receptor and the trp2 are in a protein-protein interacting complex (Fadool et al., 2001).

Chemically activated currents form the basis of electrical information passed through the vomeronasal organ to encode reproductive, social, territorial and species-recognition behavior. Further electrophysiological analysis of the biophysical properties of single VN neurons will provide the mechanistic details of signal transduction in chemical communication in vertebrates.

\section{Acknowledgments}

The authors would like to express their gratitude to Dr Mary Mendonça (Auburn University) and the Alabama Herpetology Society for assistance in trapping and for donation of research animals. We thank Mr David Watson for technical assistance in cryosectioning, Mr Charles Badland for photographic assistance, Mr John Rogers for image scanning of isolated neurons and Ms Kristal Tucker for technical assistance. We are grateful for the generosity of Dr Vince Dionne, who hosted D. Fadool in his research laboratory at the Marine Biological Laboratory, Woods Hole, MA, USA (MBL), and critically reviewed the manuscript. This research was supported by the Ann Kammer Memorial Fellowship, the Frederik Bang Fellowship and the MBL Foundation, Woods Hole, MA, USA, and by a First Year Assistant Professor Award from the Florida State University. J.H.B. was supported by NIH/NIDCD Predoctoral Chemosensory Training Grant T32-DC00044. M.W. was supported by NIH DC00378.

\section{References}

Carpenter, CC.; Ferguson, GW. Stereotyped behavior in reptiles. In: Gans, C.; Crews, D., editors. Biology of the Reptile: Hormones and Behavior. Chicago: University of Chicago Press; 1984. p. 341-419.

Chateau D, Roos J, Plas-Roser S, Roos M, Aron C. Hormonal mechanisms involved in the control of oestrous cycle duration by the odor of urine in the rat. Acta Endocrinol. 1976; 82:426-435. [PubMed: 946926]

Del Punta K, Rothman A, Rodriguez I, Mombaerts P. Sequence diversity and genomic organization of vomeronasal receptor genes in the mouse. Genome Res. 2000; 10:1958-1967. [PubMed: 11116090]

Derby CD, Hamilton KA, Ache BW. Processing of olfactory information at three neuronal levels in the spiny lobster. Brain Res. 1984; 300:311-319. [PubMed: 6145501]

Dionne VE. Chemosensory responses in isolated olfactory receptor neurons from Necturus maculosus. J. Gen. Physiol. 1992; 99:415-433. [PubMed: 1588301]

Døving KB, Trotier D. Structure and function of the vomeronasal organ. J. Exp. Biol. 1998; 201:29132925. [PubMed: 9866877]

Dulac C. Sensory coding of pheromone signals in mammals. Curr. Opin. Neurobiol. 2000; 10:511518. [PubMed: 10981622]

Eisner T, Conner WE, Hicks K, Dodge KR, Rosenberg HI, Jones TH, Cohen M, Meinwald J. Stink of stinkpot turtles identified: O-Phenylalkanoic acids. Science. 1977; 196:1347-1349. [PubMed: 17831752]

Ernst, CH.; Lovich, JE.; Barbour, RW. Turtles of the United States and Canada. Washington: Smithsonian Institute Press; 1994.

Fadool DA, Michel WC, Ache BW. Sustained primary culture of lobster (Panulirus argus) olfactory receptor neurons. Tissue Cell. 1991; 23:719-732. [PubMed: 18621183] 
Fadool DA, Michel WC, Ache BW. Odor sensitivity of cultured lobster olfactory receptor neurons is not dependent on process formation. J. Exp. Biol. 1993; 174:215-233. [PubMed: 8440966]

Fadool DA, Wachowiak M, Brann JH. Chemosignalactivated whole-cell currents in the vomeronasal (VN) organ. Chem. Senses. 2001 (in press).

Firestein S, Werblin F. Odor-induced membrane currents in vertebrate-olfactory receptor neurons. Science. 1989; 244:79-82. [PubMed: 2704991]

Friedrich R, Korsching S. Combinatorial and chemotopic odorant coding in the zebrafish olfactory bulb visualized by optical imaging. Neuron. 1997; 18:737-752. [PubMed: 9182799]

Graziadei PPC, Tucker D. Vomeronasal receptors in turtle. Z. Zellforsch. 1970; 105:498-514. [PubMed: 4919108]

Halpern M. The organization and function of the vomeronasal system. Annu. Rev. Neurosci. 1987; 10:325-362. [PubMed: 3032065]

Hamill OP, Marty A, Neher E, Sakmann B, Sigworth FJ. Improved patch-clamp techniques for highresolution current recording from cells and cell-free membrane patches. Pflügers Arch. 1981; 391:85-100.

Holy TE, Dulac C, Meister M. Responses of vomeronasal neurons to natural stimuli. Science. 2000; 289:1569-1572. [PubMed: 10968796]

Humason, GL. Animal Tissue Techniques. San Francisco: W. H.: Freeman \& Company; 1972.

Inamura K, Kashiwayanagi M. Inward current responses to urinary substances in rat vomeronasal sensory neurons. Eur. J. Neurosci. 2000; 12:3529-3536. [PubMed: 11029622]

Inamura K, Kashiwayanagi M, Kurihara K. Blockage of urinary responses by inhibitors for IP3mediated pathway in rat vomeronasal sensory neurons. Neurosci. Lett. 1997a; 233:129-132. [PubMed: 9350849]

Inamura K, Kashiwayanagi M, Kurihara K. Inositol-1,4,5-trisphosphate induces responses in receptor neurons in rat vomeronasal sensory slices. Chem. Senses. 1997b; 22:93-103. [PubMed: 9056089]

Inamura K, Matsumoto Y, Kashiwayanagi M, Kurihara K. Laminar distribution of pheromonereceptive neurons in rat vomeronasal epithelium. J. Physiol., Lond. 1999; 517:731-739. [PubMed: 10358114]

Johns MA, Feder HH, Komisaruk BR, Mayer AD. Urine-induced reflex ovulation in anovulatory rats may be a vomeronasal effect. Nature. 1978; 272:446-448. [PubMed: 565010]

Johnston RE. Pheromones, the vomeronasal system and communication. Ann. N.Y. Acad. Sci. 1998; 855:333-348. [PubMed: 9929626]

Keverne EB. The vomeronasal organ. Science. 1999; 286:716-720. [PubMed: 10531049]

Leinders-Zufall T, Lane AP, Puche AC, Ma W, Novotny MV, Shipley MT, Zufall F. Ultrasensitive pheromone detection by mammalian vomeronasal neurons. Nature. 2000; 405:792-796. [PubMed: 10866200]

Leinders-Zufall T, Rand MN, Shepherd GM, Greer CA, Zufall F. Calcium entry through cyclic nucleotide-gated channels in individual cilia of olfactory receptor cells: spatiotemporal dynamics. J. Neurosci. 1997; 17:4136-4148. [PubMed: 9151731]

Lerner MR, Gyorgyi TK, Reagan J, Roby-Shemkovitz A, Rybczynski R, Vogt RG. Peripheral events in moth olfaction. Chem. Senses. 1990; 15:191-198.

Liman ER. Pheromone transduction in the vomeronasal organ. Curr. Opin. Neurobiol. 1996; 6:487493. [PubMed: 8794101]

Liman ER, Corey DP. Electrophysiological characterization of chemosensory neurons from the mouse vomeronasal organ. J. Neurosci. 1996; 16:4625-4637. [PubMed: 8764651]

Livermore A, Hutson M, Ngo V, Hadjisimos R, Derby CD. Elemental and configural learning and the perception of odorant mixtures by the spiny lobster Panulirus argus. Physiol. Behav. 1997; 62:169-174. [PubMed: 9226358]

Lumpkin EA, Hudspeth AJ. Detection of $\mathrm{Ca}^{2+}$ entry through mechanosensitive channels localizes the site of mechanoelectrical transduction in hair cells. Proc. Natl. Acad. Sci. USA. 1995; 92:1029710301. [PubMed: 7479771] 
Luo Y, Lu S, Chen P, Wang D, Halpern M. Identification of chemoattractant receptors and G-proteins in the vomeronasal system of garter snakes. J. Biol. Chem. 1994; 269:16867-16877. [PubMed: 7515886]

Mahmoud IY. Courtship behavior and sexual maturity in four species of kinosternid turtles. Copeia. 1967; 1967:314-319.

Menzies RA, Heth G, Ikan R, Weinstein V, Nevo E. Sexual pheromones in lipids and other fractions from urine of the male mole rat, Spalax ehrenbergi. Physiol. Behav. 1992; 52:741-747. [PubMed: 1409947]

Mittman SC, Flaming DG, Copenhagen DR, Belgum JH. Bubble pressure measurement of micropipet tip outer diameter. J. Neurosci. Meth. 1987; 22:161-166.

Moss RL, Flynn RE, Shen X-M, Dudley C, Shi J, Novotny M. Urine-derived compound evokes membrane responses in mouse vomeronasal receptor neurons. J. Neurophysiol. 1997; 77:28562862. [PubMed: 9163402]

Moss RL, Flynn RE, Shi J, Shen X-M, Dudley C, Zhou A, Novotny M. Electrophysiological and biochemical responses of mouse vomeronasal receptor cells to urine-derived compounds: Possible mechanism of action. Chem. Senses. 1998; 23:483-489. [PubMed: 9759537]

Murphy FA, Tucker K, Fadool DA. Sexual dimorphism and developmental expression of signal transduction machinery in the vomeronasal organ. J. Comp. Neurol. 2001; 432:61-74. [PubMed: 11241377]

Pantages E, Dulac C. A novel family of candidate pheromone receptors in mammals. Neuron. 2000; 28:835-845. [PubMed: 11163270]

Smith DV, Travers JB. A metric for the breadth of tuning of gustatory neurons. Chem. Senses Flavour. $1979 ; 4: 215-229$.

Steel, RGD.; Torrie, JH. Principles and Procedures of Statistics: A Biometrical Approach. New York: McGraw Hill; 1980.

Taniguchi M, Dalton W, Halpern M. Chemosensitive conductance and inositol 1,4,5-trisphosphateinduced conductance in snake vomeronasal receptor neurons. Chem. Senses. 2000; 25:67-76. [PubMed: 10667996]

Taniguchi M, Kashiwayanagi M, Kurihara K. Intracellular injection of inositol 1,4,5-trisphosphate increases a conductance in membranes of turtle vomeronasal receptor neurons in the slice preparation. Neurosci. Lett. 1995; 188:5-8. [PubMed: 7540275]

Taniguchi M, Kashiwayanagi M, Kurihara K. Intracellular dialysis of cyclic nucleotides induces inward currents in turtle vomeronasal receptor neurons. J. Neurosci. 1996; 16:1239-1246. [PubMed: 8558252]

Tinkle DW. Geographic variation in reproduction size, sex ratio and maturity of Sternothaerus odoratus (Testudinata: Chelydridae). Ecology. 1961; 42:68-76.

Tirindelli R, Mucignat-Caretta C, Ryba NJP. Molecular aspects of pheromonal communication via the vomeronasal organ of mammals. Trends Neurosci. 1998; 21:482-486. [PubMed: 9829690]

Trotier D, Døving KB, Ore K, Shalchian-Tabrizi C. Scanning electron microscopy and gramicidin patch clamp recordings of microvillous receptor neurons dissociated from the rat vomeronasal organ. Chem. Senses. 1998; 23:49-57. [PubMed: 9530969]

Trotier D, Døving KB, Rosin J-F. Voltage-dependent currents in microvillar receptor cells of the frog vomeronasal organ. Eur. J. Neurosci. 1993; 5:995-1002. [PubMed: 8281316]

Vander, AJ. Renal Physiology. New York: McGraw Hill, Inc.; 1995.

Wachowiak M, Cohen LB. Presynaptic inhibition of primary olfactory afferents mediated by different mechanisms in lobster and turtle. J. Neurosci. 1999; 19:8808-8817. [PubMed: 10516300] 

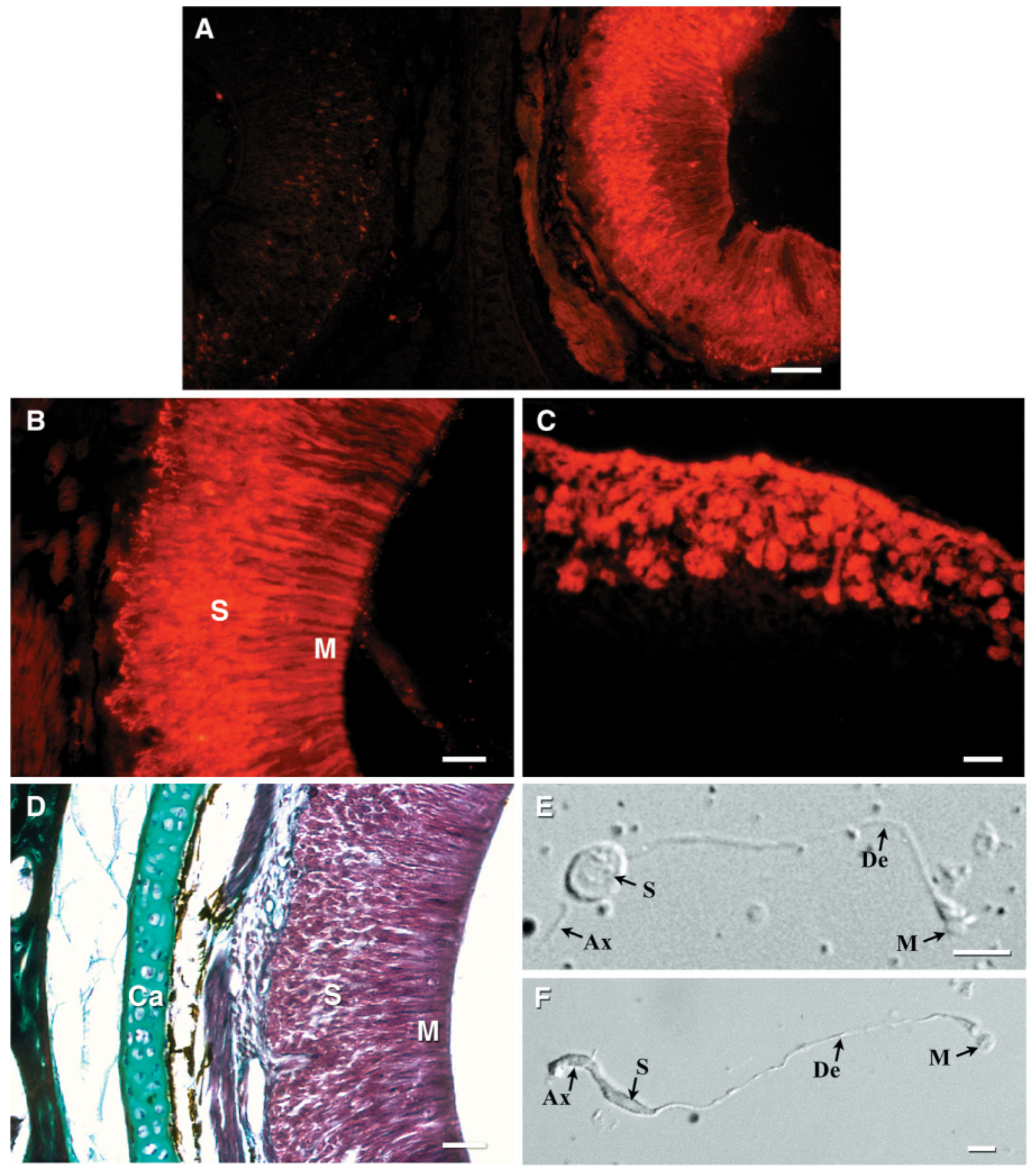

Fig. 1.

Visualization of the vomeronasal neural epithelium (VNE) of the musk turtle Sternotherus odoratus. (A) Coronal cryosection (10 $\mu \mathrm{m}$ thick) of the vomeronasal organ labeled with rhodamine-conjugated dextran to visualize the vomeronasal (VN) sensory neurons. Dextran was introduced into the left vomeronasal organ orifice and permitted to migrate for approximately 2 weeks. Note the absence of labeling on the contralateral VNE. Scale bar, 80 $\mu \mathrm{m}$. (B) Higher magnification of the section shown in A. The dendrites of the microvillar layer $(\mathrm{M})$ and more basally positioned somata $(\mathrm{S})$ are visible. Scale bar, $40 \mu \mathrm{m}$. (C) Cryosection (10 $\mu \mathrm{m}$ thick) of the dextran labeling contained in axon terminals of the VN neurons at the level of the glomeruli of the accessory olfactory bulb. Scale bar, $40 \mu \mathrm{m}$. (D) 
The same type of section and orientation as in B counterstained with Masson's Trichrome. Scale bar, $40 \mu \mathrm{m}$. (E,F) Isolated VN neurons from a female (E) and a male (F) turtle. Scale bars, $10 \mu \mathrm{m}$. Ca, cartilage; S, somata; M, microvilli; Ax, axon; De, dendrite. 


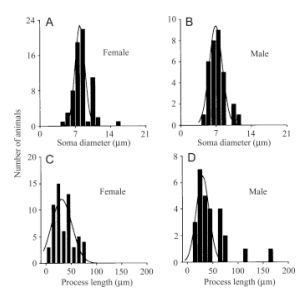

Fig. 2.

Vomeronasal (VN) neurons are sexually dimorphic in soma size. (A,B) Histograms of the soma diameter of neurons harvested from male (A) and female (B) animals. Data were plotted in $1 \mu \mathrm{m}$ bin widths and fitted with a normal distribution (solid line). The mean soma diameter of female VN neurons was significantly larger than that of males; Student's $t$-test, $\alpha=0.05$. (C,D) As in A and B but for total neurite process length. Data were less well fitted by a normal distribution and not significantly different between female and male VN neurons (Student's $t$-test, $\alpha=0.05$ ). 

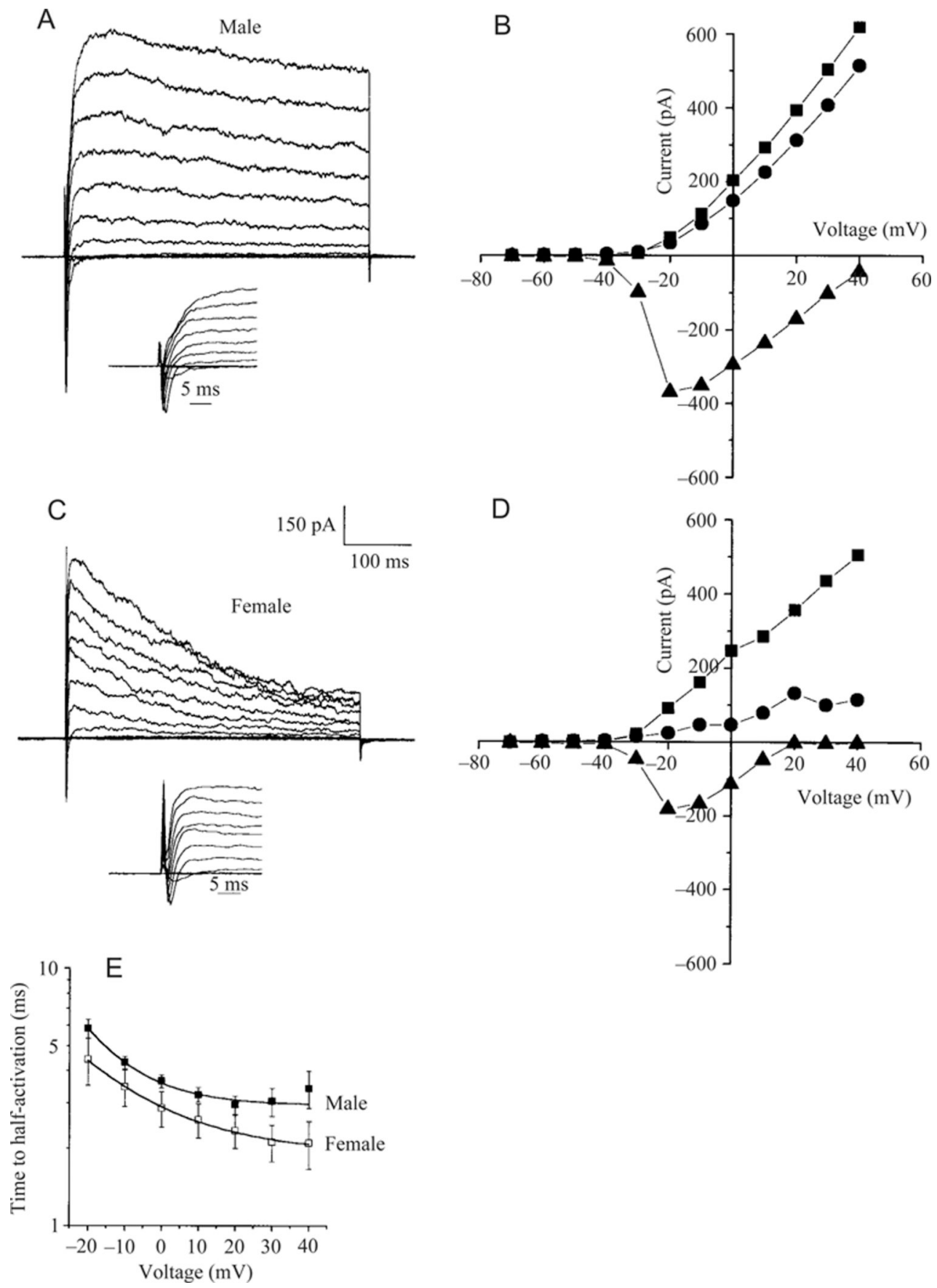

Fig. 3.

Representative patch-clamp recordings from Sternotherus odoratus vomeronasal (VN) neurons in the whole-cell configuration. Holding potential, $V_{\mathrm{h}},-70 \mathrm{mV}$. Neurons were stepped in $10 \mathrm{mV}$ depolarizing command potentials to $+40 \mathrm{mV}$ for $400 \mathrm{~ms}$ with an interpulse interval of $10 \mathrm{~s}$. (A) Whole-cell current recording from a male $\mathrm{VN}$ neuron. (B) Current/voltage curves were plotted from the family of currents shown in A for the peak inward current ( $\mathbf{\Lambda})$ and the peak transient $(\boldsymbol{\bullet})$ and sustained $(\bullet)$ components of the outward current. (C,D) As in A and B but for a female VN neuron. Note that the outward currents of the female inactivated more rapidly than those of the male (see Results for calculations). The insets in $\mathrm{A}$ and $\mathrm{C}$ are the same recording on an expanded time scale to allow visualization of 
the rapid inward current and kinetics of activation. (E) Time to half-activation of the outward voltage-activated current measured from male $(\mathbf{m} ; N=5)$ and female $(\square ; N=19) \mathrm{VN}$ neurons. Note that the vertical axis is on a logarithmic scale. Values are means \pm s...м. 

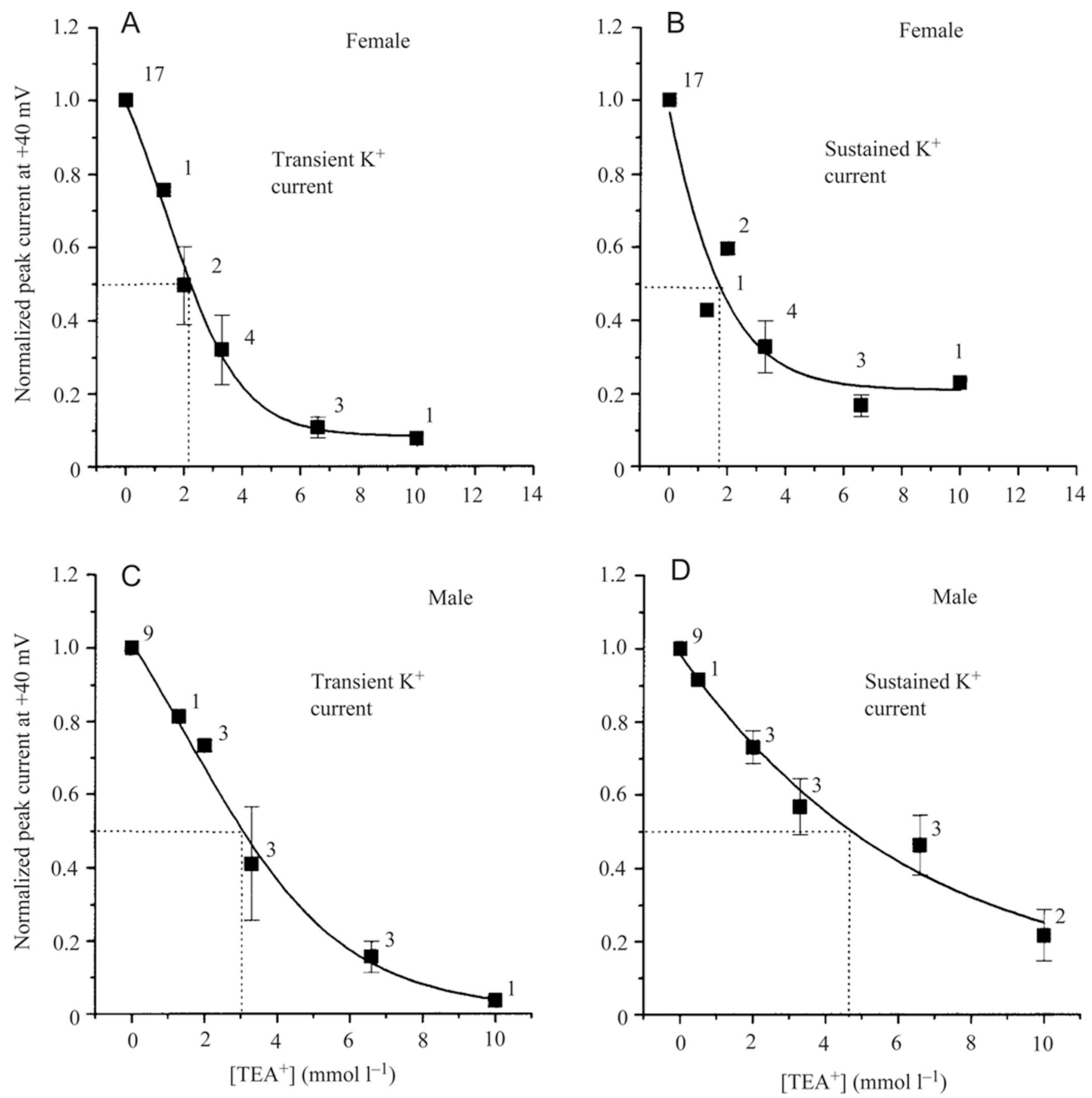

Fig. 4.

$\mathrm{K}^{+}$current block by tetraethylammonium $\left(\mathrm{TEA}^{+}\right)$is dissimilar between male and female vomeronasal (VN) neurons. Dose/response curves for $\mathrm{TEA}^{+}$block of $\mathrm{K}^{+}$currents in female $(\mathrm{A}, \mathrm{B})$ and male $(\mathrm{C}, \mathrm{D}) \mathrm{VN}$ neurons. Whole-cell currents were elicited using the voltage stimulation protocol described in Fig. 3, and neurons were pretreated with $20 \mathrm{nmol} \mathrm{l}^{-1}$ tetrodotoxin (TTX) to isolate predominantly outward currents. The initial current at $+40 \mathrm{mV}$ depolarization was normalized to that after a 5 min incubation with bath-applied $\mathrm{TEA}^{+}$at various concentrations. Peak transient current was measured $50 \mathrm{~ms}$ after the beginning of the voltage stimulation, and peak sustained current was measured at the end of the $400 \mathrm{~ms}$ duration of the voltage stimulation. The smooth curves are fits to a single-exponential decay, 
where $y=y_{0}+A \mathrm{e}^{-\left(x-x_{0}\right) t}$, with a half-maximal inhibition concentration $\left(K_{\mathrm{i}}\right)$ for the transient $\mathrm{K}^{+}$ current of $2.4 \mu \mathrm{mol} \mathrm{l}^{-1}$ and $2.0 \mu \mathrm{mol} \mathrm{l^{-1 }}$ for male and female neurons, respectively. The sustained $\mathrm{K}^{+}$current had a $K_{\mathrm{i}}$ of $4.8 \mu \mathrm{mol}^{-1}$ and $1.7 \mu \mathrm{mol} \mathrm{l}^{-1}$ for male and female neurons, respectively. Values are means \pm s..... (sample sizes are given on the figure). 
A

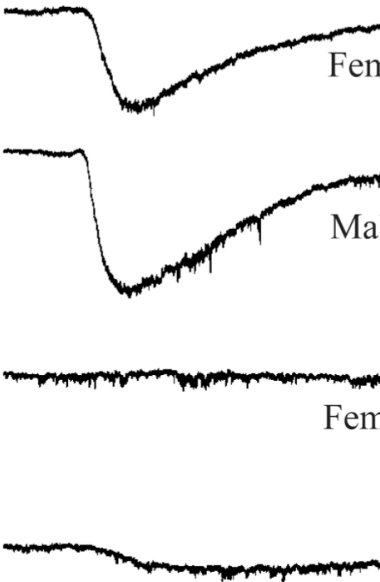

Male urine
B

Female musk
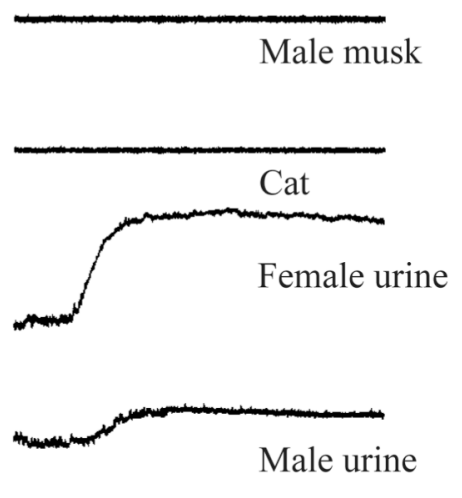

Ringer

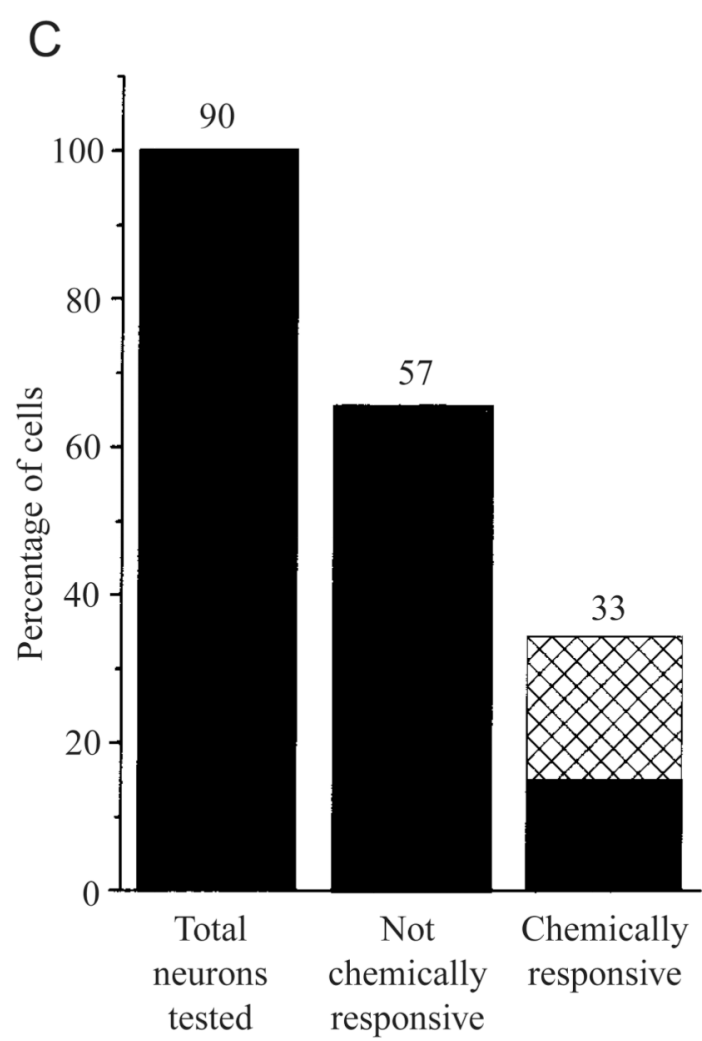

Fig. 5.

Vomeronasal $(\mathrm{VN})$ neurons are chemically activated by multiple natural compounds. (A) Whole-cell, voltage-clamp recording from a female $\mathrm{VN}$ neuron in response to stimulating the cell (black bar) with a 1:100 dilution of female musk, a 1:100 dilution of male musk, a 1:10 dilution of female urine, a 1:10 dilution of male urine and turtle Ringer alone. Holding potential, $V_{\mathrm{h}}$, was $-60 \mathrm{mV}$ for all traces. Chemical stimulation lasted $700 \mathrm{~ms}$. (B) Wholecell, voltage-clamp recording from a male $\mathrm{VN}$ neuron. This neuron displays the typical outward current observed in both genders in response to urine. Cat, catfish extract. (C) Histogram of the percentage of 90 neurons displaying chemically evoked currents in response to at least one of five natural stimuli tested per neuron as in A or B. The filled area of the column on the far right shows the percentage of neurons responding to only one of the five natural chemicals, and the hatched area of the column shows the percentage of neurons responding to two or more of the five test chemicals. Sample sizes are given on the figure. 

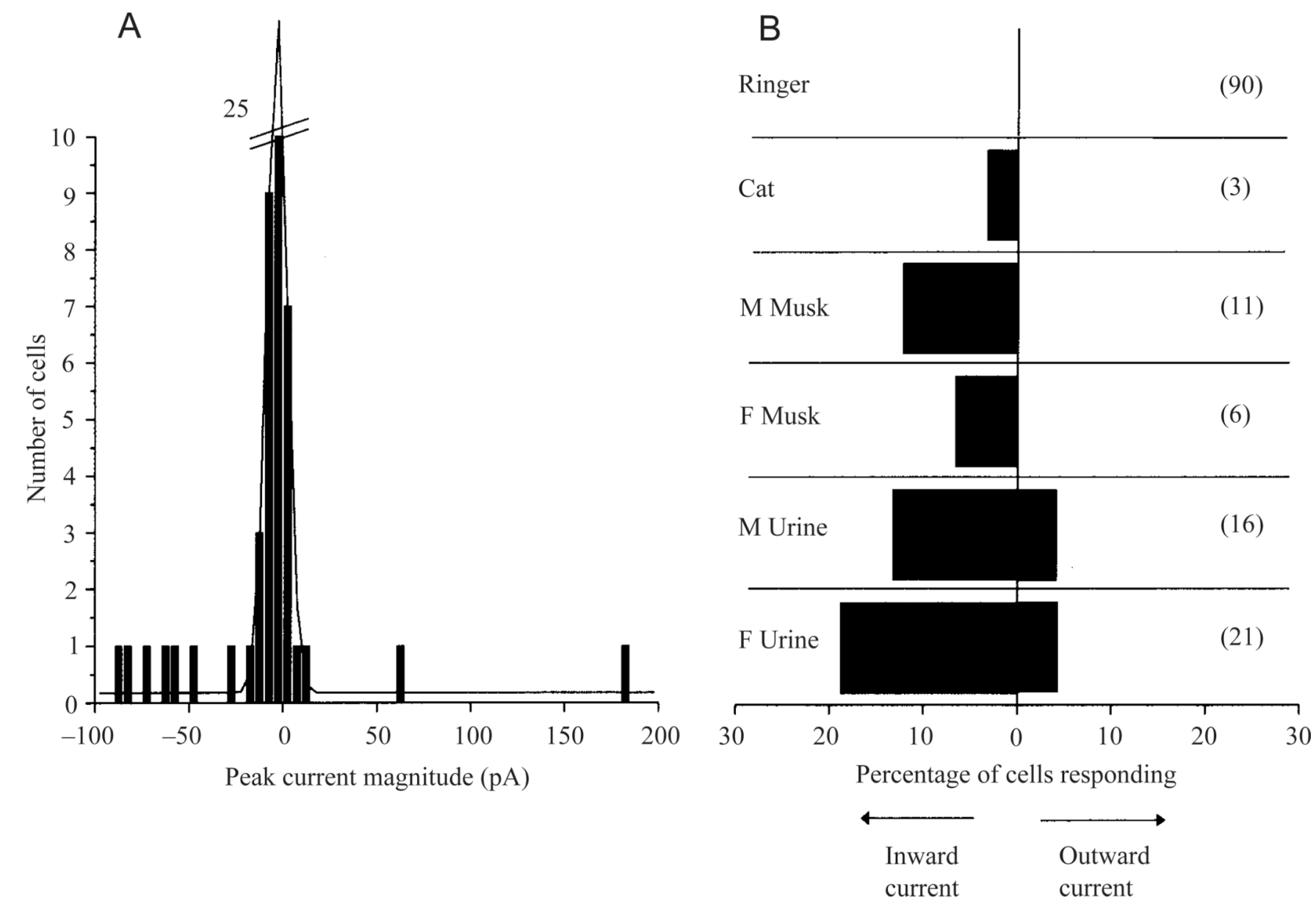

Fig. 6.

Vomeronasal (VN) neurons elicit both inward and outward currents in response to chemical stimulation. (A) Plot of the distribution of the peak current magnitude in response to exposure to five natural stimuli. The most frequent response magnitudes were between -15 and $+15 \mathrm{pA}$. Data were fitted with a bin width of $10 \mathrm{pA}$ and with a normal distribution (solid line) to approximate the mean frequency. Zero current responses are not plotted. (B) Plot of the percentage of VN neurons that respond to the stimuli with inward and outward currents. Urine was tested at a dilution of 1:10, musk at a dilution of 1:300 and catfish extract at a dilution of 1:100. The number of neurons tested is given in parentheses. Cat, catfish extract; M Musk, male musk; F Musk, female musk; M Urine, male urine; F Urine, female urine. 
A

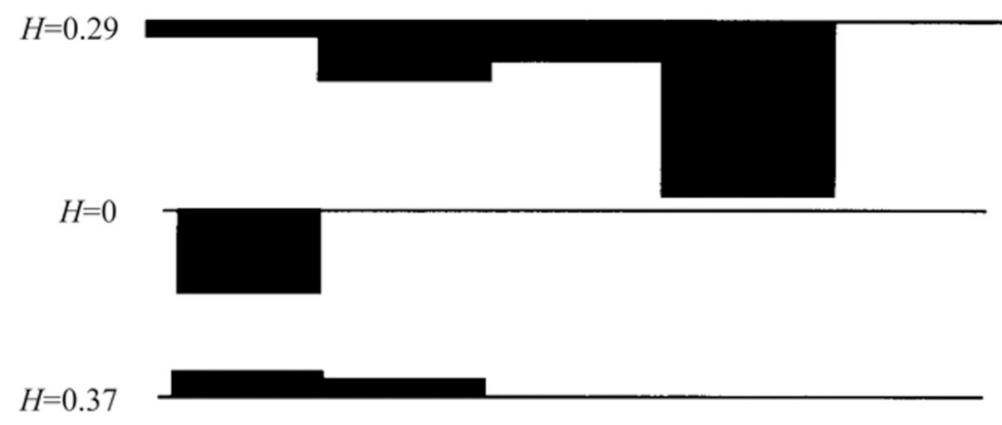

$H=0.13$
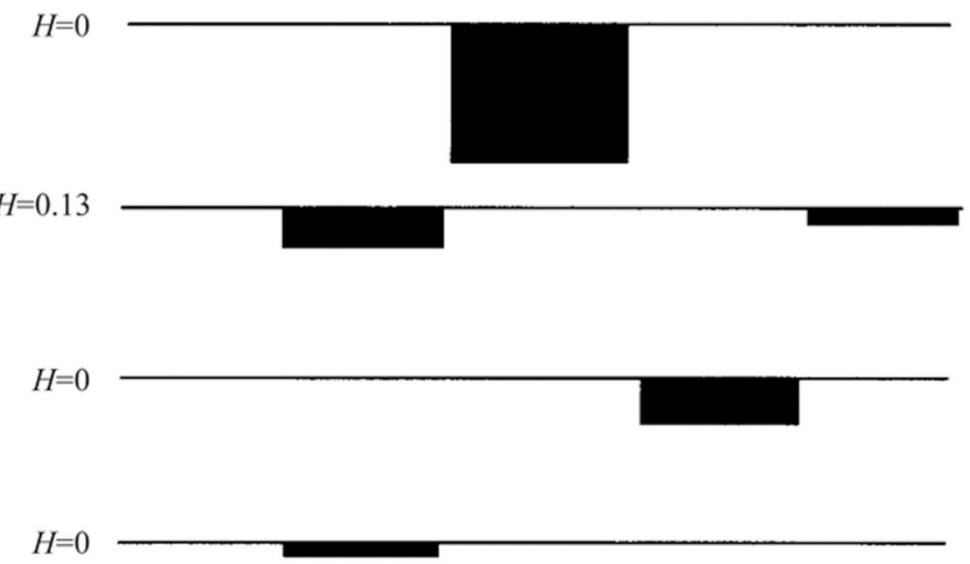

$H=0.39$
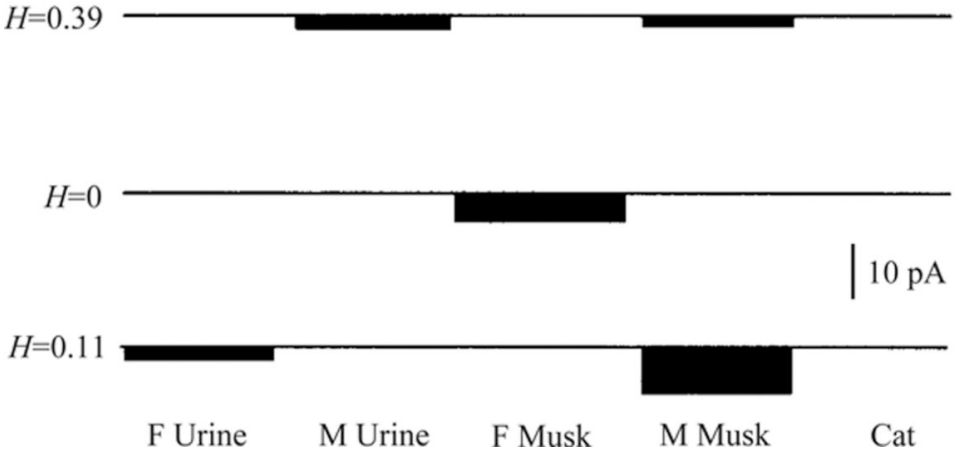

Fig. 7.

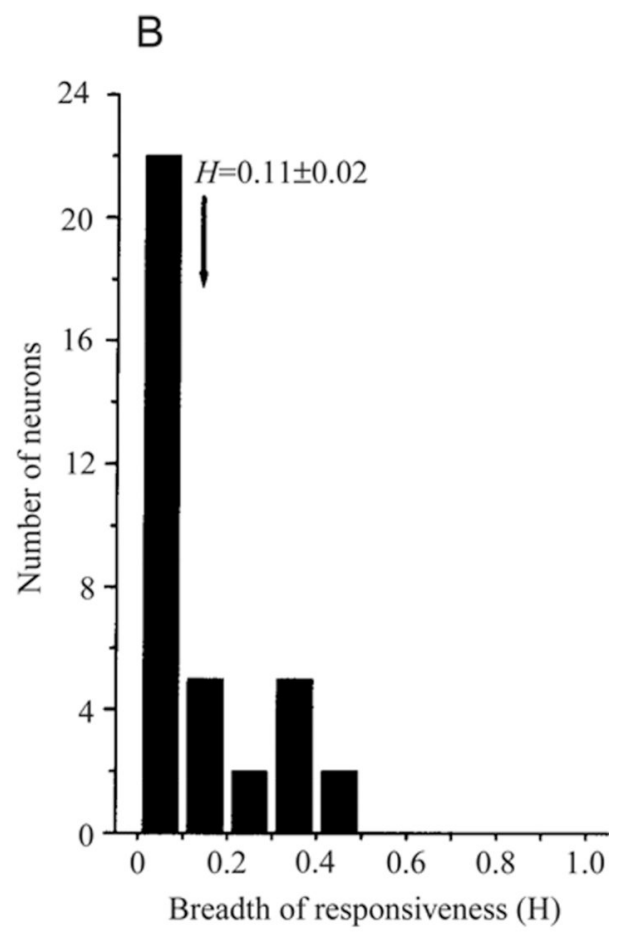

The breadth of responsiveness of vomeronasal ( $\mathrm{VN}$ ) neurons indicates a degree of diversity on the basis of entropy calculations. (A) The response profiles of $10 \mathrm{VN}$ neurons to five chemicals. Each horizontal line depicts the responses of a different neuron; the height of the columns on each line indicates the amplitude and the direction of the columns indicates the polarity of the chemically evoked current (pA). The outward currents are denoted as positive (upward columns) and the inward currents are denoted as negative (downward columns). The calculated $H$ metric for a given neuron is presented to the left of each response profile. Breadth of responsiveness is minimal $(H=0)$ when a $\mathrm{VN}$ neuron responds to only one of five chemicals (narrow selectivity) and it is maximal $(H=1.0)$ when there is an equal response to 
each of the five chemicals (no selectivity or low diversity in response). (B) Histogram of the breadth of responsiveness of 36 neurons. The arrow denotes the mean $H$ value $(0.11 \pm 0.02$, mean \pm S.E.M.) (see Materials and methods for calculation). Cat, catfish extract; M Musk, male musk; F Musk, female musk; M Urine, male urine; F Urine, female urine. 
Table 1

Voltage-activated properties of vomeronasal neurons acutely isolated from male and female Sternotherus odoratus

\begin{tabular}{lcll}
\hline $\begin{array}{l}\text { Peak transient outward current } \\
(\mathbf{p A})\end{array}$ & $\begin{array}{c}\text { Peak sustained outward current } \\
(\mathbf{p A})\end{array}$ & $\begin{array}{l}\text { Peak inward current } \\
(\mathbf{p A})\end{array}$ & $\begin{array}{l}\text { Inactivation time constant, } \tau, \\
\text { for the outward current } \\
(\mathbf{m s})\end{array}$ \\
\hline $\begin{array}{l}\text { Males } \\
647.1 \pm 70.1(25)\end{array}$ & $352.1 \pm 61.3(25)$ & $418.7 \pm 55.2^{*}(25)$ & $447.7 \pm 54.3^{*}(25)$ \\
Females & & & $302.7 \pm 47.0(83)$ \\
$546.6 \pm 35.3(83)$ & $298.8 \pm 29.2(83)$ & $292.5 \pm 24.3(83)$ & \\
\hline
\end{tabular}

Neurons were voltage-clamped at $-70 \mathrm{mV}$ and stepped to depolarized potentials in $10 \mathrm{mV}$ increments for $400 \mathrm{~ms}$. In total, 108 recordings were made from 24 animals (five male and 19 female).

Peak outward current was measured at the height of the transient component of the current at the $+40 \mathrm{mV}$ step.

Peak sustained current was measured at the end of the $+40 \mathrm{mV}$ voltage step, using the same stimulation protocol.

Peak inward current was measured at the $-20 \mathrm{mV}$ step.

The inactivation rate constant of the outward current was determined from single-exponential fits to the $+40 \mathrm{mV}$ step calculated by minimizing the sums of squares.

Values are means \pm S.E.M. (number of neurons sampled).

* Significantly different across genders by Student's $t$-test $(\alpha=0.05)$. 
Table 2

Properties of vomeronasal neurons acutely isolated from male and female Sternotherus odoratus

\begin{tabular}{lcc}
\hline $\begin{array}{l}\text { Chemosignal } \\
\text { stimulus }\end{array}$ & $\begin{array}{c}\text { Peak } \\
\text { inward current } \\
(\mathbf{p A})\end{array}$ & $\begin{array}{c}\text { Peak } \\
\text { outward current } \\
(\mathbf{p A})\end{array}$ \\
\hline Males $(N=5)$ & $-3.6 \pm 0.9(6)$ & $2.25(1)$ \\
Female urine & $-3.1 \pm 0.7(3)$ & None \\
Male urine & None & None \\
Female musk & None & None \\
Male musk & None & None \\
Catfish extract & None & None \\
Ringer & & \\
Females $(N=13)$ & $-9.3 \pm 3.7(12)$ & $63.4 \pm 28.9(3)$ \\
Female urine & $-7.3 \pm 1.5(9)$ & $27.2 \pm 14.0(5)$ \\
Male urine & $-37.2 \pm 13.5(6)$ & None \\
Female musk & $-21.1 \pm 8.4(11)$ & None \\
Male musk & $-2.8 \pm 0.3(3)$ & None \\
Catfish extract & None & None \\
Ringer & & \\
\hline & & \\
\hline
\end{tabular}

Neurons were voltage-clamped at $-60 \mathrm{mV}$, a membrane potential determined to be below that required to elicit voltage-activated currents.

Ninety neurons from 18 animals were tested with five chemical stimuli and Ringer. Values are means \pm S.E.M. (number of neurons sampled). 